\title{
Flow cytometry as a tool in the evaluation of blood leukocyte function in Chelonia mydas (Linnaeus, 1758) (Testudines, Cheloniidae)
}

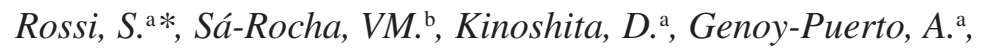 \\ Zwarg, T. ${ }^{\mathrm{c}}$, Werneck, MR. ${ }^{\mathrm{d}}$, Sá-Rocha, LC. ${ }^{\mathrm{e}}$ and Matushima, ER. ${ }^{\mathrm{e}}$ \\ aPrograma de Pós-Graduação em Patologia Experimental e Comparada, \\ Faculdade de Medicina Veterinária e Zootecnia - FMVZ, Universidade de São Paulo - USP \\ Av. Prof. Dr. Orlando Marques de Paiva, 87, CEP 05508-900, Cidade Universitária, São Paulo, SP, Brazil

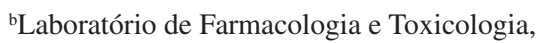 \\ Faculdade de Medicina Veterinária e Zootecnia - FMVZ, Universidade de São Paulo - USP \\ Av. Prof. Dr. Orlando Marques de Paiva, 87, CEP 05508-900, Cidade Universitária, São Paulo, SP, Brazil \\ 'Iniciação Científica, Faculdade de Medicina Veterinária e Zootecnia - FMVZ, Universidade de São Paulo - USP, \\ Av. Prof. Dr. Orlando Marques de Paiva, 87, CEP 05508-900, Cidade Universitária, São Paulo, SP, Brazil

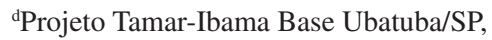 \\ Rua Antonio Atanázio, 273, CEP 11680-000, Itaguá, Ubatuba, SP, Brazil \\ eDepartamento de Patologia Faculdade de Medicina Veterinária e Zootecnia - FMVZ, Universidade de São Paulo - USP \\ Av. Prof. Dr. Orlando Marques de Paiva, 87, CEP 05508-900, Cidade Universitária, São Paulo, SP, Brazil \\ *e-mail: rossi.silmara@yahoo.com.br
}

Received December 3, 2007 - Accepted February 19, 2008 - Distributed 31 August, 2009

(With 15 figures)

\begin{abstract}
Chelonia mydas is a sea turtle that feeds and nests on the Brazilian coast and a disease called fibropapillomatosis is a threat to this species. Because of this, it is extremely necessary to determine a methodology that would enable the analysis of blood leukocyte function in these sea turtles. In order to achieve this aim, blood samples were collected from C. mydas with or without fibropapillomas captured on the São Paulo north coast. Blood samples were placed in tubes containing sodium heparin and were transported under refrigeration to the laboratory in sterile RPMI 1640 cell culture medium. Leukocytes were separated by density gradient using Ficoll-Paque ${ }^{\mathrm{TM}}$ Plus, Amershan Biociences ${ }^{\circledR}$. The following stimuli were applied in the assessment of leukocyte function: Phorbol Miristate-Acetate (PMA) for oxidative burst activity evaluation and Zymosan A (Saccharomyces cerevisiae) Bio Particles ${ }^{\circledR}$, Alexa Fluor ${ }^{\circledR} 594$ conjugate for phagocytosis evaluation. Three cell populations were identified: heterophils, monocytes and lymphocytes. Monocytes were the cells responsible for phagocytosis and oxidative burst.
\end{abstract}

Keywords: Chelonia mydas, green turtle, leukocytes, flow cytometry.

\section{A citometria de fluxo como ferramenta para avaliar a função celular de leucócitos sangüíneos de Chelonia mydas (Testudines, Cheloniidae)}

\section{Resumo}

Chelonia mydas é uma tartaruga marinha que freqüenta o litoral brasileiro para alimentação e nidificação e uma doença denominada fibropapilomatose é uma das mais importantes ameaças à sobrevivência dessa espécie. Desta forma, a definição de uma metodologia que permita analisar a função dos leucócitos sangüíneos torna-se extremamente necessária. Foram utilizadas amostras sangüíneas de $C$. mydas com e sem fibropapilomas capturadas no litoral norte do estado de São Paulo. As amostras sangüíneas foram colocadas em tubos contendo heparina sódica e transportadas em meio de cultura celular RPMI 1640 estéril e sob refrigeração. Os leucócitos foram obtidos por gradiente de densidade usando Ficoll-Paque ${ }^{\mathrm{TM}}$ Plus, Amershan Biociences ${ }^{\circledR}$. Os estímulos aplicados foram Miristato Acetato de Phorbol (PMA) para avaliação de burst oxidativo e Zymosan A (Saccharomyces cerevisiae) Bio Particles ${ }^{\circledR}$, Alexa Fluor ${ }^{\circledR} 594$ conjugate para avaliação de fagocitose. Foram identificadas três populações celulares: heterófilos, monócitos e linfócitos. Os monócitos foram as células responsáveis pela fagocitose e pelo burst oxidativo.

Palavras-chave: Chelonia mydas, tartaruga verde, leucócitos, citometria de fluxo. 


\section{Introduction}

Chelonia mydas, the green turtle, feeds and nests on the coastal area of Brazil. A debilitating disease called fibropapillomatosis is one of the greatest threats to the survival of this species. This disease is characterised the occurrence of benign skin tumours, called fibropapillomas (FP).

Lesions caused by fibropapillomatosis may interfere in the hydrodynamic function and motility of these animals (Adnyana, Ladds and Blair, 1997) and may be debilitating and fatal (Aguirre et al., 1998). There were cases in which tumours disappeared and others in which they increased in size or quantity (Jacobson et al., 1989; Ehrhart, Sindler and Witherington, 1986; Ehrhart, 1991). Fibropapillomatosis is the greatest responsible agent for the mortality and morbidity of this species in Hawaiian Islands (Work and Balazs, 1997).

In Brazil, the first studies carried out in order to better understand the etiology of the tumours in sea turtles employed histopathological, immunohistochemical, ultrastructural, hematological and biochemical analyses (Matushima et al., 1999; 2001; Matushima, 2003).

Demographic development, as well as industrial and agricultural activities may contribute for the increase in the incidence of the disease (Balazs, 1991; Adnyana, Ladds and Blair, 1997), and some studies suggest the involvement of toxic pollutants and biotoxins (Ehrhart, 1991; Balazs, 1991). Data obtained in Ubatuba - São Paulo, indicated that prevalence increased from 0 to 24\%, in the period between 1986 and 1998. In Vitória - Espírito Santo, the prevalence of the disease reached $40 \%$ in 2000 (Baptistotte et al., 2001).

Green turtles seem to be able to show humoral response, and stress and nutrition are important modulators of immune function. Immunological changes may represent the final stage of the disease (Cray et al., 2001). Due to the fact that turtles affected by the disease are immunosuppressed, the evaluation of blood leukocyte function is extremely necessary. This may be achieved by means of flow cytometry, a technique widely used nowadays.

\section{Material and Methods}

\subsection{Turtles, forms and sites of capture and collection of blood samples}

Blood samples were collected from 5 turtles, 2 of them showing fibropapillomas and 3 without tumours. Animals were captured at different beaches in the city of Ubatuba, located in the Northern coast of the state of

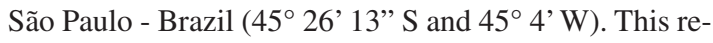
gion was selected due to the constant presence of young green turtles feeding in the coastal area. Turtles were incidentally captured in fishing nets or stuck on the beach and were taken to the technicians at Projeto TamarIbama, Ubatuba/SP Base. After capture, animals were kept in captivity until they were fit to be released again.
The cervical venous sinus was punctured for blood collection, using the occipital bone as the reference for its location. Around $10 \mathrm{~mL}$ of blood were collected after asepsis of the site, and one aliquot was used in for the blood extensions. Biometry data (size, quantity and distribution of the papillomas) were also recorded.

Blood samples were collected in tubes containing sodium heparin. One aliquot of blood was used in flow cytometry and another in the hemogram. For flow cytometry, $1 \mathrm{~mL}$ blood was diluted in $3 \mathrm{~mL}$ of RPMI 1640 Gibco $^{\circledR}$ culture medium (using a Bunsen burner to prevent contamination), in order to keep cells viable. All samples were transported under refrigeration to the laboratories at the University of São Paulo.

\subsection{Collection of leukocytes for flow cytometry}

Leukocytes were obtained using Ficoll-Paque ${ }^{\mathrm{TM}}$ Plus Amersham Biosciences ${ }^{\circledR}$ in 2 densities, 1.070 and 1.055 g.mL ${ }^{-1}$. For each blood sample, $4 \mathrm{~mL}$ of Ficoll 1.070 g.mL $\mathrm{mL}^{-1}$ were placed in a $15 \mathrm{~mL}$ Falcon ${ }^{\circledR}$ tube and then $4 \mathrm{~mL}$ of Ficoll 1.055 g.mL ${ }^{-1}$ were slowly added. After that, $4 \mathrm{~mL}$ of blood diluted in RPMI were slowly added by the walls of the tube. Immediately after this preparation, tubes were centrifuged in a refrigerated Sanyo ${ }^{\circledR}$ Harrier model 18/80 centrifuge during 45 minutes, at $450 \times \mathrm{g}, 18{ }^{\circ} \mathrm{C}$, brake 4 . After centrifugation, leukocyte agglomerates were removed using a Pasteur pipette and were placed in a $15 \mathrm{~mL}$ Falcon ${ }^{\circledR}$ tube containing $10 \mathrm{~mL}$ of phosphate-buffered saline (PBS) $1 \times$. Tubes were centrifuged again for 10 minutes, $18{ }^{\circ} \mathrm{C}, 300 \times \mathrm{g}$, brake 4 (the procedure was performed two consecutive times in order to completely remove Ficoll from the samples, due to its detrimental effect on cells after prolonged contact). The supernatant was discarded and $1 \mathrm{~mL}$ of PBS $1 \times$ was added to the pellet.

\subsection{Preparation of the samples for in vitro stimulation}

Viable cells were counted in the central reticule of a Neubauer counting chamber using Trypan blue 1:9 ( $90 \mu \mathrm{L}$ of Trypan blue in $10 \mu \mathrm{L}$ of the sample). At least $95 \%$ of the cells had to be viable in order to be submitted to the induction procedure. After determining the percentage of viable cells, suspensions were adjusted to $4 \times 10^{5}$ leukocytes/mL of sample. The volume of each sample was calculated to contain this cell concentration. For each sample, tubes were organized as follows:

- Tube A: cell suspension - control;

- Tube B: cells + DCFH (2' 7' dichlorofluorescein) evaluation of basal oxidative burst activity;

- Tube C: cells + DCFH + PMA (Phorbol MiristateAcetate) - evaluation of chemically induced oxidative burst activity; and

- Tube D: cells + Zymosan A (Saccharomyces cereviseae) BioParticles ${ }^{\circledR}, \quad$ Alexa Fluor $^{\circledR} 594$ conjugate - evaluation of phagocytosis.

Tubes were incubated for 50 minutes at room temperature, away from light, and were manually stirred every 10 minutes. Evaluation of blood leukocyte cell 
function was carried out in a flow cytometer model FACs Calibur from Becton Dickinson Immunocytometry Systems ${ }^{\circledR}$, San José, CA, USA, connected to an Apple ${ }^{\circledR}$ Macintosh G4. Data collected were analysed by means of Cell Quest Pro (Becton Dickinson Immunocytometry Systems). A total of 20,000 events were used.

\subsection{Preparation of the samples for sorting}

Sorting was necessary to determine leukocyte populations analysed in the cytometer. Preparation of the samples after blood collection was the same described above, with samples collected from 5 turtles ( 3 showing fibropapillomas and 2 with no tumours).

Leukocytes were obtained using Ficoll-Paque ${ }^{\mathrm{TM}}$ Plus Amersham Biosciences ${ }^{\circledR}$ in 2 densities, 1.070 and $1.055 \mathrm{~g} . \mathrm{mL}^{-1}$ as described before. The supernatant was discarded and $1 \mathrm{~mL}$ of sterile PBS $1 \times$ enriched with $1 \%$ of bovine fetal serum (SFBFS) was added to the pellet.

Viable cells were counted in the central reticule of a Neubauer counting chamber using Trypan blue 1:9 ( $90 \mu \mathrm{L}$ of Trypan blue in $10 \mu \mathrm{L}$ of the sample). The suspension of cells was submitted to a passage in a $23 \mathrm{G}$ needle $(25 \times 6)$ in order to eliminate particles that could prevent the flow in the cytometer. Each sample was prepared to have $3 \times 10^{6}$ leukocytes $/ \mathrm{mL}$. Cells were kept in sterile PBS $1 \times$ enriched with $1 \%$ BFS during the whole cytometer acquisition in order to maintain cell viability. A cytometer model FACs Vantage from Becton Dickinson Immunocytometry Systems ${ }^{\circledR}$, San José, CA, USA, connected to an Apple ${ }^{\circledR}$ Macintosh G4 was used. Suspensions were collected in test tubes containing 1,000 $\mu \mathrm{L}$ of RPMI 1640.

Some samples produced more than one tube with $3 \times 10^{6}$ cells $/ \mathrm{mL}$. Three individual cell populations, called R1, R2 and R3, were determined and separated in individual tubes. In order to obtain an adequate number of cells to make the slides, the sum of R 1 of each sample was carried out in one tube, R2 in another and R3 in a third one. These 3 resulting tubes were centrifuged in a refrigerated centrifuge Sanyo ${ }^{\circledR}$ Harrier model 18/80 for 5 minutes, at $450 \times \mathrm{g}, 4{ }^{\circ} \mathrm{C}$. After centrifugation, the pellet was placed in a cytological centrifuge to make the slides.

\section{Results}

Total leukocyte count was carried out using the method by Natt and Herrick (1952) and differential count was carried out using blood extensions stained by the modified Rosenfeld (1947) technique. Cells observed were identified as Monocytes (Mon.), Lymphocytes (Lym.), Heterophils (Het.) and Eosinophils (Eos.) (Tables 1 and 2). In order to demonstrate the kinds of leukocytes separated by Ficoll density gradients, non-induced samples were used to produce microscopy slides in a cytological centrifuge Fanem ${ }^{\circledR}$ model 248 . Results of these counts are shown in Tables 3 and 4. For the phagocytosis analysis, a slide was assembled using a Zymosan A-stimulated sample. The slides were stained by the modified Rosenfeld (1947) technique.

Leukocyte populations were analyzed by the software Cell Quest Pro ${ }^{\circledR}$ (Becton Dickison Immunocytometry Systems) for Macintosh ${ }^{\circledR}$. The cytogram showed the distribution of the cells according to their internal complexity and size. This is graphically shown in a random scale in which each point corresponds to a cell. Three populations were observed by means of Ficoll-Paque ${ }^{\mathrm{TM}}$ Plus after sorting (Figure 1), shown in the cytogram SSC $\times$ FSC (Side Scatter Channel $\times$ Forward Scatter Channel). Enough events were obtained for slide production and to validate the cell populations (Table 5). Distribution of leukocyte populations in turtles without or with tumours are shown in Figures 2 and 3.

Table 1. Differential leukocyte counts in Chelonia mydas without fibropapillomas.

\begin{tabular}{lllccc}
\hline \multicolumn{1}{c}{ Sample } & Mon. & Lym. & Het. & Eos. & Total \\
\hline T36 & 500 & 1375 & 10625 & - & 12500 \\
T37 & 920 & 1610 & 8970 & - & 11500 \\
T38 & 100 & 1350 & 3500 & 50 & 5000 \\
Mean & 506.67 & 1445 & 7698.33 & 16.67 & 9666.67 \\
Standard Deviation & 410.04 & 143.44 & 3728.84 & 28.87 & 4072.26 \\
\hline
\end{tabular}

Table 2. Differential leukocyte counts in Chelonia mydas with fibropapillomas.

\begin{tabular}{llcccc}
\hline \multicolumn{1}{c}{ Sample } & Mon. & Lym. & Het. & Eos. & Total \\
\hline T31 & 380 & 2375 & 6555 & 190 & 9500 \\
T34 & 140 & 180 & 1640 & 40 & 2000 \\
Mean & 260 & 1277.5 & 4097.5 & 115 & 5750 \\
Standard Deviation & 169.71 & 1552.1 & 3475.43 & 106.07 & 5303.30 \\
\hline
\end{tabular}


Table 3. Differential leukocyte counts in Chelonia mydas without fibropapillomas, after separation using Ficoll.

\begin{tabular}{llcccc}
\hline \multicolumn{1}{c}{ Sample } & Mon. & Lym. & Het. & Eos. & Total \\
\hline T36 & 78 & 7 & 15 & - & 100 \\
T37 & 84 & 3 & 13 & - & 100 \\
T38 & 51 & 17 & 16 & 16 & 100 \\
Mean & 71 & 9 & 14.67 & 5.33 & - \\
Standard & 17.58 & 7.21 & 1.53 & 9.24 & - \\
Deviation & & & & & \\
\hline
\end{tabular}

Table 4. Differential leukocyte counts in Chelonia mydas showing fibropapillomas, after separation using Ficoll.

\begin{tabular}{llclcc}
\hline Sample & Mon. & Lym. & Het. & Eos. & Total \\
\hline T31 & 48 & 14 & 10 & 28 & 100 \\
T34 & 31 & 8 & 61 & - & 100 \\
Mean & 39.5 & 11 & 35.5 & 14 & - \\
Standard & 12.02 & 4.24 & 36.06 & 19.8 & - \\
Deviation & & & & & \\
\hline
\end{tabular}

Table 5. Number of events acquired in sorting.

\begin{tabular}{cc}
\hline Gate & Number of events obtained in sample T19 \\
\hline R1 & 312,960 \\
R2 & 14,382 \\
R3 & 179,533 \\
\hline
\end{tabular}

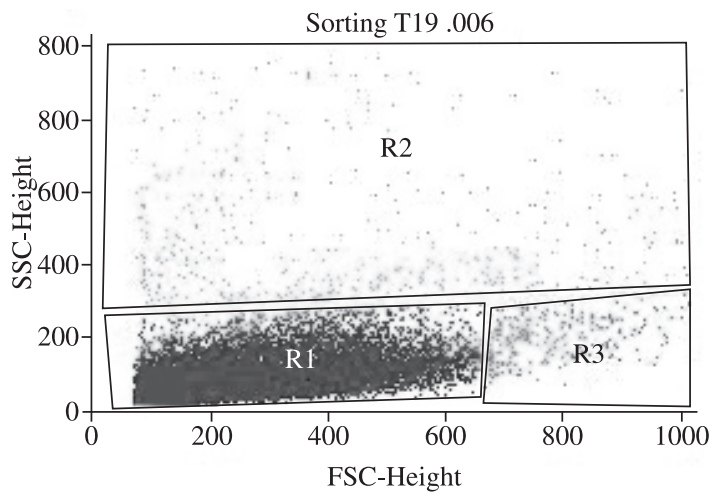

Figure 1. Leukocyte populations observed by means of Ficoll-Paque ${ }^{\mathrm{TM}}$ Plus $^{\circledR}$. R1: Lym., R2: Het., R3: Mon.

Fluorescence intensity in monocytes from turtles with or without fibropapillomatosis may be observed in Figures 4 and 5, respectively. The intensity of fluorescence in monocytes stimulated by Zymosan is represented in Figures 6 and 7. Intensity of basal oxidative burst in monocytes of turtles not affected and affected by the disease is shown in Figures 8 and 9. The intensity of oxi-

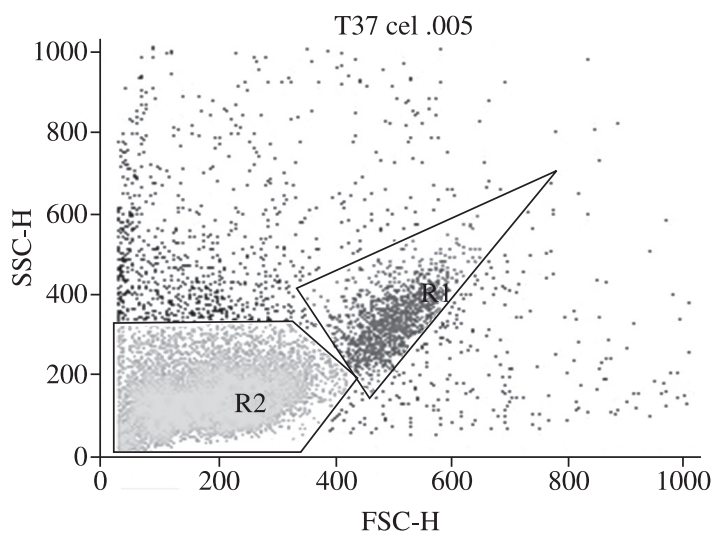

Figure 2. Leukocyte populations of Chelonia mydas without tumours. R1: Mon, R2: Lym.

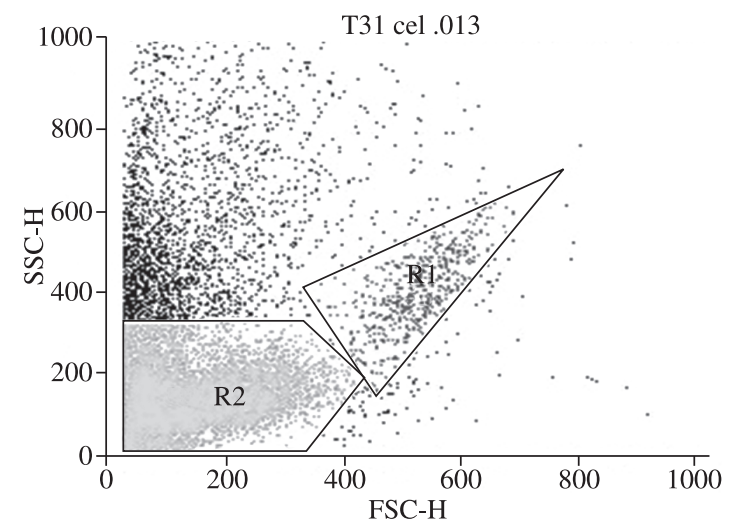

Figure 3. Leukocyte populations of Chelonia mydas with tumours. R1: Mon, R2: Lym.

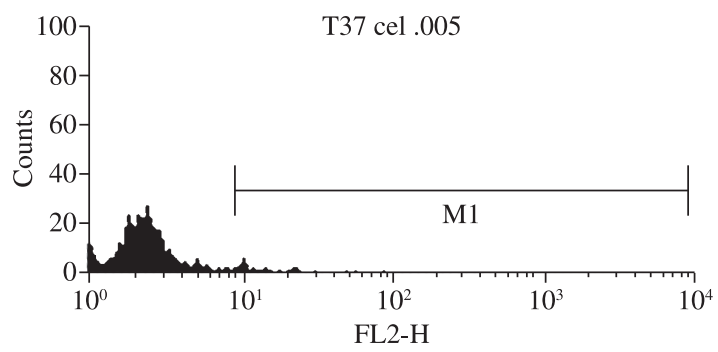

Figure 4. Fluorescence intensity in monocytes of Chelonia mydas without tumours.

dative burst induced by PMA is represented in Figures 10 and 11 . There were no statistical differences between turtles with or without fibropapillomas in relation to phagocytosis intensity (Figure 12), basal (Figure 13) and PMAinduces oxidative burst (Figure 14). The Figure 15 show the monocytes phagocyting Zymosan A. These results are due to the extremely reduced number of Chelonia mydas 


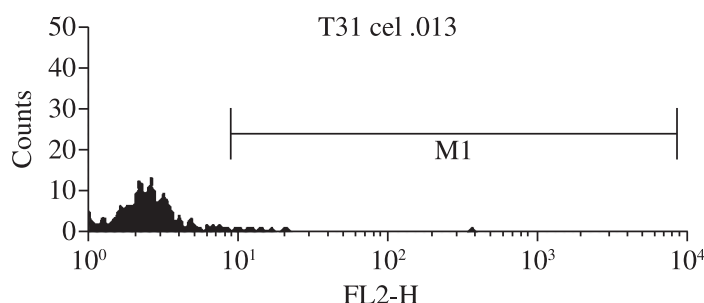

Figure 5. Fluorescence intensity in monocytes of Chelonia mydas with tumours.

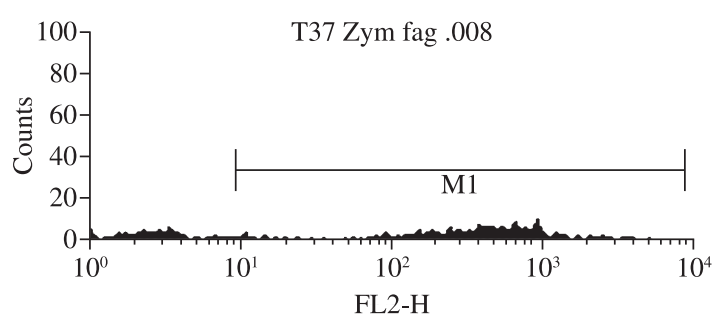

Figure 6. Phagocytosis intensity in monocytes of Chelonia mydas without tumours.

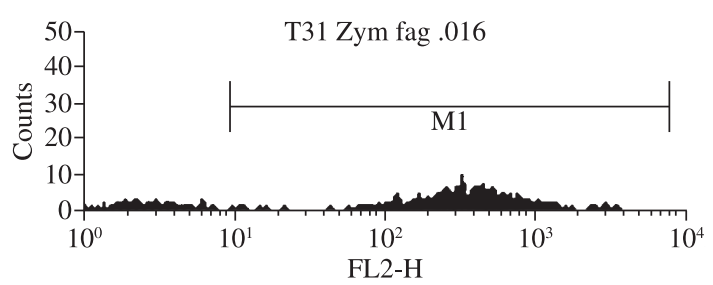

Figure 7. Phagocytosis intensity in monocytes of Chelonia mydas with tumours.

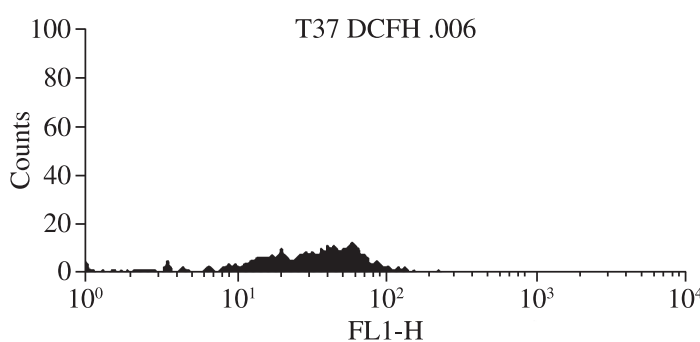

Figure 8. Intensity of the basal oxidative burst activity of Chelonia mydas without tumours.

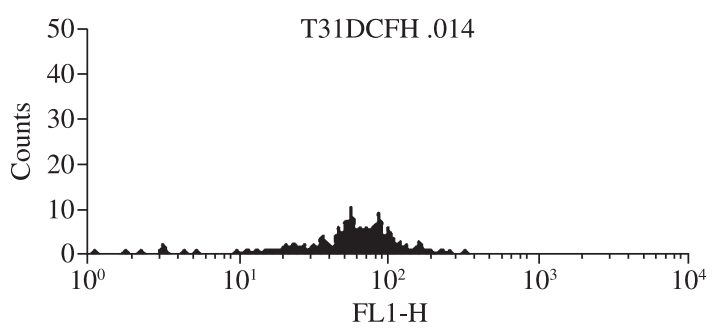

Figure 9. Intensity of the basal oxidative burst activity of Chelonia mydas with tumours.

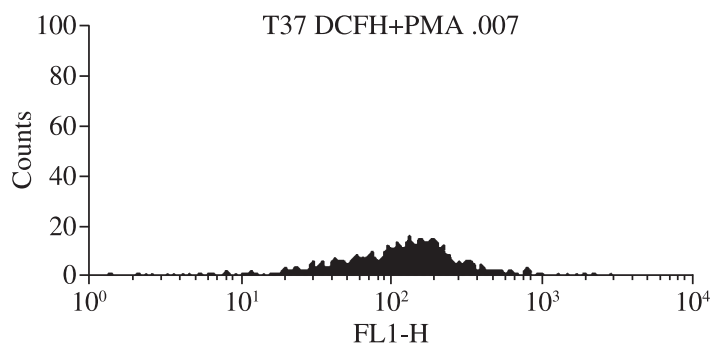

Figure 10. Intensity of oxidative burst activity stimulated by PMA in Chelonia mydas without tumours.

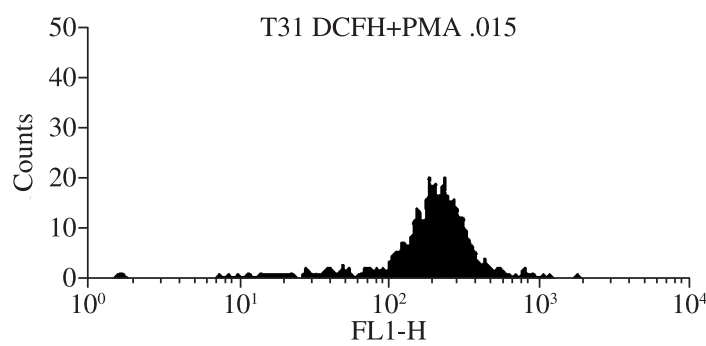

Figure 11. Intensity of oxidative burst activity stimulated by PMA in Chelonia mydas with tumours.

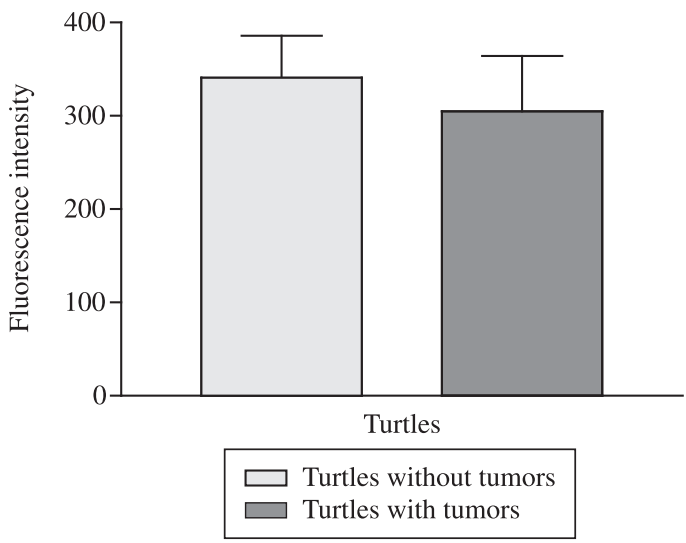

Figure 12. Intensity of phagocytosis. 


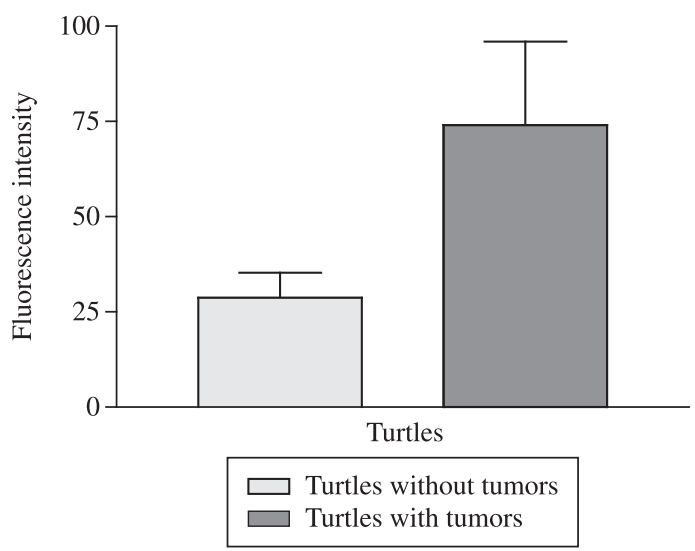

Figure 13. Intensity of basal oxidative burst activity.

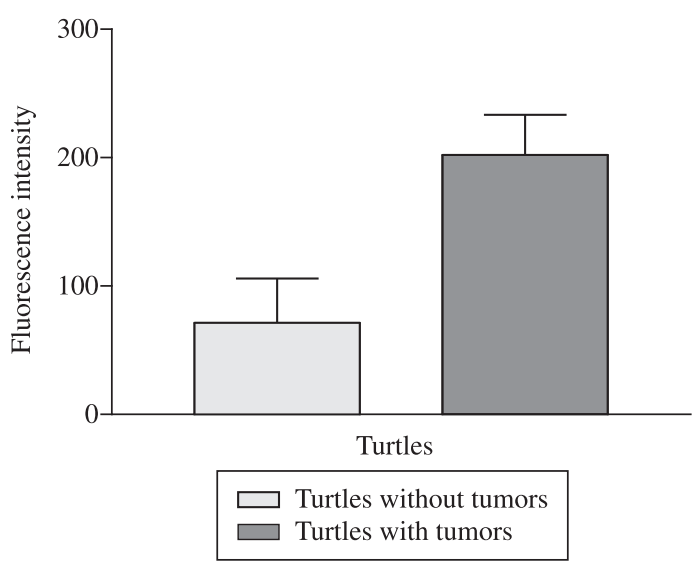

Figure 14. Intensity of oxidative burst activity stimulated by PMA.

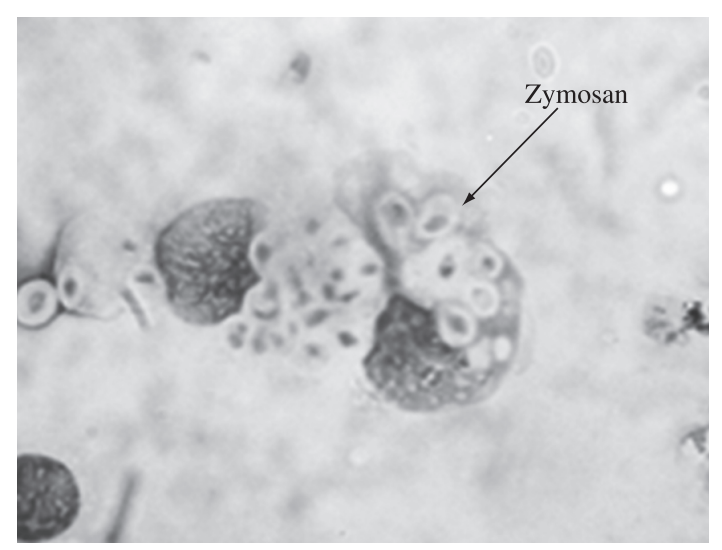

Figure 15. Monocytes phagocyting Zymosan A. Objective $100 \times$.

studied. Results obtained by sorting, together with the analysis of fluorescence intensity in the cells enabled the confirmation that monocytes were the cells responsible both for the oxidative burst and phagocytosis.

\section{Discussion and Final Considerations}

Results showed that RPMI 1640 kept cells viable and enabled leukocytes to respond to the stimuli applied. Ficoll-Paque ${ }^{\mathrm{TM}}$ Plus densities used were efficient in the separation of mononuclear cells and heterophils. The cells that were responsible for the reaction to the stimuli applied were monocytes, both in the evaluation of the oxidative burst activity and phagocytosis. This fact was corroborated by the statistical analysis and by the slides produced, in which Zymosan A was clearly seen in the cytoplasm of the monocytes. Fluorescence intensity showed no significance in the evaluation of the basal or stimulated oxidative burst activities or phagocytosis in turtles with or without fibropapillomas.

The pathogenesis of fibropapillomatosis is still unclear and the disease is a threat to survival of C. mydas, because it affects young green turtles. Diseases related with pollution are a relevant factor for the reduction of animal population and ecosystem imbalance.

This study enabled the development of a flow cytometry methodology that was able to evaluate the cell function of blood leukocytes of Chelonia mydas. However, it is necessary to increase the number of Chelonia mydas with or without fibropapillomas evaluated in future studies in order to obtain more concrete and relevant results for the hyphothesis that animals affected by fibropapillomatoris show immunosupression.

Acknowledgements — Projeto Tamar-Ibama, Ubatuba/SP base, Departamento de Patologia at the Faculty of Veterinary and Zootechnical Medicine - University of São Paulo; CAPES for the Master's degree grant and Fapesp for the financial support.

\section{References}

ADNYANA, W., LADDS, PW., BLAIR, D., 1997. Observations of fibropapillomatosis in green turtles (Chelonia mydas) in Indonesia. Australian Veterinary Journal, vol. 75, no. 10, p. 737-742.

AGUIRRE, AA., SPRAKER, TR., BALAZS, GH. and ZIMMERMAN, B., 1998. Spirorchids and fibropapillomas in green turtles from the Hawaiian Islands. Journal of Wildlife Diseases, vol. 34, no. 1, p. 91-98.

BALAZS, GH., 1991. Current status of fibropapillomas in the Hawaiian green turtle, Chelonia mydas. In: BALAZS, GH., POOLEY, SG. (Ed.). Research plan for marine turtle fibropapilloma. U.S.: U. S. Department of Commerce, National Oceanographic and Atmospheric Administration, National Marine Fisheries Service. p. 47-57.

BAPTISTOTTE, C., SCALFONE, JT., GALLO, BMG., SANTOS, AS., CASTILHOS, JC., LIMA, EHSM. et al., 2001. Prevalence of sea turtle fibropapillomatosis in Brazil. In: Proceedings the 21 Annual Symposium on Sea Turtle Biology and Conservation. Philadelphia: [s.n.]. p. 24-28.

CRAY, C., VARELLA, R., BOSSART, GD., LUTZ, P., 2001. Altered in vitro immune responses in green turtles (Chelonia mydas) with fibropapillomatosis. Journal of Zoo and Wildlife Medicine, vol. 32, no. 4, p. 436-440. 
EHRHART, LM., 1991. Fibropapillomas in green turtles of the Indian River lagoon, Florida: distribution over time and area. [S.1.]: National Oceanic and Atmospheric Administration; National Marine Fisheries Service. p. 59-61.

EHRHART, LM., SINDLER, RB. and WITHERINGTON, BE. 1986. Preliminary investigation of papillomatosis in green turtles: phase I - frequency and effects on turtles in the wild and in captivity. U.S.: U.S. Department of Commerce; National Oceanographic and Atmospheric Administration; National Marine Fisheries Service; Miami Laboratory. 46 p. (Contract no. 40- GENF-6-00601, Final Report).

JACOBSON, ER., MANSELL, JL., SUNDBERG, JP., HAJAR, L., REICHMANN, MM. and EHRHART, LM. et al., 1989. Cutaneous fibropapillomas of green turtles (Chelonia mydas). Journal of Comparative Pathology, vol. 101, no. 1, p. 39-52.

MATUSHIMA, ER. 2003. Fibropapilomas em tartarugas marinhas: aspectos histológicos, imuno-histoquímicos e ultraestruturais. São Paulo: Faculdade de Medicina Veterinária e Zootecnia, Universidade de São Paulo. 111 f. [Tese de LivreDocente em Patologia].

MATUSHIMA, ER., LONGATTO-FILHO, A., DI LORETTO, C., KANAMURA, CT., RAMOS, MCC., SINHORINI, IL. and GALLO, B. 2001. Cutaneous papillomas of green turtles: a morphological, ultrastructural and immunohistochemical study in Brazilian specimens. Brazilian Journal of Veterinary Research and Animal Science, vol. 38, no. 2, p. 51-54.

MATUSHIMA, ER., LONGATTO-FILHO, A., DI LORETTO, C., KANAMURA, CT., GALLO, B. and BAPTISTOTTE, C. 1999. Cutaneous papillomas of green turtles: a morphological and immunohistochemical study in brazilian specimens. In: Proceedings of the 19 Annual Symposium on Sea Turtle Conservation and Biology. U.S.: U. S. Dep. Commer. NOAA Tech. Memo. p. 237-239.

NATT, MP., HERRICK, GA. 1952. A new blood diluent for counting erythrocytes and leukocytes of the chicken. Poultry Science, vol. 31, p. 735-738.

ROSENFELD, G. 1947. Método rápido de coloração de esfregaços de sangue: noções práticas sobre corantes pancromáticos e estudo de diversos fatores. Memórias do Instituto Butantan, vol. 20, p. 315-328.

WORK, TM., BALAZS, GH. 1997. Causes of green turtle (Chelonia mydas) morbidity and mortality in Hawaii. In: Proceedings of the 17 Annual Symposi in the Sea Turtle Biology and Conservation. Florida: [s.n.]. 